\title{
ROZWIĄZANIE SPÓŁKI WODNEJ W PRAWIE POLSKIM
}

\section{DISSOLUTION OF WATERBOARDS IN POLISH LAW}

\section{STRESZCZENIE}

Spółka wodna w obecnym stanie prawnym uregulowana została ustawą z dnia 18 lipca 2001 r. Prawo wodne. W ustawie tej przewidziane zostały dwa sposoby rozwiązania spółki wodnej. Pierwszym $\mathrm{z}$ nich jest uchwała walnego zgromadzenia, natomiast drugim decyzja uprawnionego organu czyli starosty. Jednak zaistnienie któregokolwiek ze wskazanych zdarzeń nie powoduje automatycznego ustania bytu prawnego spółki wodnej, natomiast prowadzi do otwarcia postępowania likwidacyjnego. W okresie trwania postępowania likwidacyjnego spółka wodna działa pod dotychczasową nazwą, jednak z dodaniem wyrazów $w$ likwidacji, zachowując osobowość prawną. Moment utraty przez spółkę wodną osobowości prawnej nie został uregulowany ustawą Prawo wodne i wzbudza wiele wątpliwości.

* Magister prawa, doktorantka KPOŚ WPiA UMK w Toruniu. 


\begin{abstract}
Słowa kluczowe wodnej

Spółka wodna, rozwiązanie spółki wodnej, likwidacja spółki
\end{abstract}

\title{
ABSTRACT
}

Water board is regulated in the Water Law Act of 18 July 2001. In current regulations there are two ways to dissolve the water board. The first is a resolution of general assembly and the second is a decision of authorized body i.e. starost. The events referred to above do not cause losing the legal existence of water board automatically but cause the opening of liquidation proceedings. During the liquidation proceedings water board carries out under the name of the company but with the additional words ,in liquidation" retaining legal personality. The exact time of losing legal personality by water board is not regulated in the Water Law so that is questionable.

\section{Keywords} board

Water board, dissolution of water board, liquidation of water

Spółka wodna w obecnym stanie prawnym uregulowana została ustawą z dnia 18 lipca 2001 r. Prawo wodne'. Spółki wodne posiadają długie tradycje na ziemiach polskich sięgające okresu połowy XIX w. $^{2}$ Po raz pierwszy do polskiego ustawodawstwa wprowadzone zostały ustawą wodną z dnia 19 września $1922 \mathrm{r}^{3}$ Przepisy dotyczące spółek wodnych, mimo iż w zmienionej treści, znalazły swoje miejsce również w ustawie Prawo wodne z 30 maja 1962 r. $^{4}$, która uchyliła ustawę wodną z 1922 r. oraz w ustawie Prawo wodne z dnia 24 października 1974 r. ${ }^{5}$, która poprzedzała obecne regulacje. Z uwagi na brak definicji ustawowej pojęcia „spółka wodna” definicje takie

1 Tekst jednolity Dz.U. 2012, Nr 145, powoływana dalej również jako Prawo wodne.

2 R. Paczuski, Spótki wodne. Historia. Podstawy prawne działania. Nowe tendencje, Warszawa 1989, s. 15 i nast.

3 Dz. U. 1922, Nr 102, poz. 936.

2/2012 4 Dz. U. 1962, Nr 34, poz. 158.

5 Dz. U. 1974, Nr 38, poz. 230. 
stworzono w literaturze przedmiotu, jednak nie są one ze sobą zgodne.

Pierwsza definicja traktuje pojęcie spółki wodnej bardzo szeroko, określając ją jako formę rozwijania aktywności społecznej, charakteryzującą się wysokim stopniem nadzoru administracji publicznej, który obejmuje jej tworzenie, funkcjonowanie oraz likwidację. Trzy inne definicje, które zostały stworzone w literaturze przedmiotu w sposób wyraźny określają, czym jest ta aktywność społeczna. Jedna z nich określa, iż istotę spółki wodnej stanowi samorząd gospodarczy, stąd też spółka wodna definiowana jest jako „gospodarcza organizacja samorządowa dla realizacji zadań gospodarki wodnej"'. Kolejna koncepcja wiąże pojęcie spółki wodnej z innymi funkcjonującymi w polskim porządku prawnym spółkami: spółkami prawa cywilnego oraz spółkami prawa handlowego. Wyróżniono trzecią grupę spółek - spółki prawa administracyjnego - do których zaliczono spółkę wodną . Według ostatniego prezentowanego w literaturze przedmiotu poglądu spółka wodna jest to „zrzeszenie osób fizycznych i prawnych, które nie działają w celu osiągnięcia zysku, lecz zaspokojenia wskazanych ustawą potrzeb w dziedzinie gospodarowania wodami".

Jak wynika z tytułu niniejszego opracowania, przedmiot rozważań stanowi rozwiązanie spółki wodnej w prawie polskim. Rozwinięte zostaną konkretne problemy związane z przedmiotowym zagadnieniem a w szczególności uznaniowy charakter decyzji starosty w przedmiocie rozwiązania spółki wodnej oraz moment utraty przez spółkę osobowości prawnej.

6 J. Rotko [w:] Prawo wodne. Komentarz pod red. J. Rotki, Wrocław 2002, s. 409.

7 R. Paczuski, Spótki wodne - cele, zadania, prawne podstawy organizacji oraz perspektywy ich rozwoju w kontekście zachodzacych zmian, Toruń 2006, s. 16, K.I. Kobus-Ogrodniczak, Korzystanie z wód - problemy prawne, Toruń 2011, s. 119, M. Ciepaj, Spótki wodne w systemie gospodarki wodnej, Opole 1989, s. 42. Definicja spółki wodnej jako gospodarczej organizacji samorządowej do spraw gospodarki wodnej znalazła się również w Wielkiej Encyklopedii Prawa pod red. E. Smoktunowicza, Białystok 2000, s. 951-953.

8 J. Szachułowicz, Prawo wodne. Komentarz, Warszawa 2010, s. 404.

9 I. Koza, L. Osuch-Chacińska, M. Pełda-Sypuła, M. Rytlewski, Nowe prawo wodne, Zielona Góra 2002, s. 166. 
Obecnie obowiązująca ustawa Prawo wodne przewiduje szczególny tryb rozwiązania spółki wodnej. Regulacja ta, mimo iż związana z ustaniem bytu prawnego podmiotu, którego cele i zadania zostały konkretnie określone $\mathrm{w}$ art. 164 ust. 2 ustawy Prawo wodne, dysponującego majątkiem, w skład którego wchodzi również mienie nieruchome, została zawarta w zaledwie pięciu przepisach wspomnianej ustawy a mianowicie w art. 181-184.

W ustawie Prawo wodne przewidziane zostały dwa sposoby rozwiązania spółki wodnej. Pierwszym z nich jest uchwała walnego zgromadzenia, natomiast drugim decyzja uprawnionego organu czyli starosty. Jednak zaistnienie któregokolwiek ze wskazanych zdarzeń nie powoduje automatycznego ustania bytu prawnego spółki wodnej, natomiast prowadzi do otwarcia postępowania likwidacyjnego.

Analizując pierwszy z wymienionych sposobów, który został określony w art. 181 ust. 1 Prawa wodnego, można zauważyć, iż dla rozwiązania spółki mocą uchwały walnego zgromadzenia ustawodawca nie przewidział konieczności zaistnienia ustawowo określonych przyczyn. Oznacza to, że ich określenie pozostawiono w gestii walnego zgromadzenia, którego uprawnienia charakteryzują się najszerszym zakresem i największą powagą. Kompetencje tego organu zostały określone w art. 173 ustawy Prawo wodne a realizowane sa przez uprawnienie do podejmowania uchwał. Warto wspomnieć, iż do kompetencji walnego zgromadzenia należy nadzór nad spółką w zakresie jej działalności. Z tego wynika, że na podstawie uchwały walnego zgromadzenia w statucie można określić okoliczności, których zaistnienie będzie skutkowało jej rozwiązaniem. W rozporządzeniu Rady Ministrów z dnia 20 lipca 1979 r. w sprawie spółek wodnych i ich związków ${ }^{10}$, które stanowiło akt wykonawczy do ustawy Prawo wodne z 24 października lipca 1974 r., wyraźnie wskazywano w § 32 ust. 1, że uchwałą walnego zgromadzenia rozwiązuje się spółkę wodną $\mathrm{w}$ przypadku zaistnienia takich zdarzeń prawnych jak: upływ czasu, na który spółka została zawarta - w przypadku zawarcia spółki na czas oznaczony, osią- 
gnięcie celu spółki, czy też jeżeli przemawiają za tym względy gospodarcze. Jak już wspomniano obecnie obowiązująca ustawa Prawo wodne określenie przyczyn rozwiązania spółki wodnej uchwałą walnego zgromadzenia pozostawia w gestii tego organu. Jednak, jak się wydaje, do tych przyczyn, ze względu na ich wagę, można zaliczyć również podział spółki, utratę pozwolenia wodno-prawnego, czy też zaistnienie okoliczności, których nie można pogodzić z celami spółki, dla których została utworzona. W statucie spółki można określić, iż ich zaistnienie będzie skutkowało rozwiązaniem spółki wodnej. Co istotne, walne zgromadzenie może podjąć uchwałę o rozwiązaniu spółki również $\mathrm{w}$ razie zaistnienia określonych okoliczności, które nie zostały przewidziane $\mathrm{w}$ uchwalonym statucie, czy też po prostu jeżeli taki wniosek zostanie złożony a następnie przyjęty w drodze uchwały walnego zgromadzenia ${ }^{11}$.

Należy jednak pamiętać o tym, iż powód rozwiązania spółki wodnej nie może być sprzeczny z prawem lub ze statutem spółki. W przeciwnym wypadku starosta, zgodnie z kompetencjami, które zostały mu przyznane na mocy art. 179 prawa wodnego, ma uprawnienie do stwierdzenia w drodze decyzji administracyjnej nieważności uchwały organów spółki wodnej ${ }^{12}$.

Uchwały sprzeczne $\mathrm{z}$ prawem lub statutem, również uchwała o rozwiązaniu spółki, są nieważne ex lege, zaś decyzja starosty w tej kwestii ma jedynie charakter deklaratoryjny, gdyż stanowi ona jedynie potwierdzenie zaistnienia nieważności ${ }^{13}$. W tej kwestii warto przytoczyć tezę wyroku Wojewódzkiego Sądu Administracyjnego w Lublinie z dnia 20 maja 2008 r., II SA/Lu 186/08, Lex nr 500767, który stwierdził, że $w$ związ$k u$ z tym, iz $w$ kompetencji nadzorczej starosty nad działalnościa spółek wodnych nie mieści się uchylenie uchwały, a jedynie stwierdzenie jej nieważności, użyte $w$ art. 179 ust. 4 ustawy z dnia 18 lipca 2001 r. Prawo wodne (Dz. U. Nr 98, poz. 1071 ze zm.) sformułowanie „uchwała została uchylona” uznać należy za sy-

11 J. Szachułowicz, op. cit., s. 437, 424-425.

12 I. Koza, L. Osuch-Chacińska, M. Pełda-Sypuła, M. Rytlewski, op. cit., s. $176-177$.

13 J. Szachułowicz, op. cit., s. 433. 
nonim „stwierdzenia nieważności uchwaty”. Zatem, ostateczna decyzję starosty $w$ przedmiocie stwierdzenia nieważności uchwat walnego zgromadzenia spótki wodnej, można zakwestionować $w$ drodze wniosku o ponowne rozpatrzenie sprawy, a następnie, po wyczerpaniu trybu administracyjnego, $w$ drodze skargi do wojewódzkiego squdu administracyjnego.

Należy również rozważyć problem częściowej nieważności uchwały o rozwiązaniu spółki wodnej. Co prawda w art. 179 ust. 2 ustawy Prawo wodne uregulowano możliwość wydawania decyzji w sprawie częściowej nieważności uchwały, jednakże ustawa ta nie przewiduje możliwości, którą na gruncie prawa cywilnego daje art. 58 § 3 ustawy z dnia 23 kwietnia 1964 r. kodeks cywilny ${ }^{14}$, a mianowicie stwierdzenia nieważności całej uchwały walnego zgromadzenia w przypadku, kiedy dotknięta była ona nieważnością tylko w części, jednak z okoliczności wynika, iż nie podjęto by uchwały bez postanowień dotkniętych nieważnością. W obliczu takiej sytuacji, w literaturze przedmiotu zaproponowano przyjęcie rozwiązania analogicznego do przedstawionego w art. 58 § $3 \mathrm{k}$.c., czyli wydania decyzji o nieważności całej uchwały ${ }^{15}$.

Co więcej, na mocy przepisów art. 178-180 Prawa wodnego, które odnoszą się do kompetencji kontrolnych i nadzorczych, przyznano również staroście prawo do wstrzymania wykonania uchwały o rozwiązaniu spółki wodnej. Wyposażenie organu kontrolnego w taką możliwość ma doniosłe znaczenie w przypadku zakończenia bytu spółki, gdyż zamyka drogę do wszczęcia postępowania likwidacyjnego.

Na zakończenie rozważań dotyczących kompetencji starosty wzakresie możliwości unieważniania uchwał walnego zgromadzenia o rozwiązaniu spółki wodnej, należy wskazać, iż decyzja starosty orzekającego o nieważności uchwały jest decyzją ostateczną. W przypadku takiego rozstrzygnięcia organ spółki może wnieść jedynie o ponowne rozpoznanie sprawy, nie może natomiast wnosić odwołania. Rozwiązanie to wykorzystuje instytucję prawną zawartą w art. 127 § 3 ustawy z dnia 14 czerw-

14 Dz. U. 1964, Nr 16, poz. 93 ze zm. powoływana dalej jako k.c.

15 J. Szachułowicz, op. cit., s. 434. 
ca 1960 r. kodeks postępowania administracyjnego ${ }^{16}$ odnoszącą się do decyzji wydawanych przez naczelne i centralne organy administracji rządowej ${ }^{17}$. Rozwiązanie zawarte w Prawie wodnym różni się jednak istotnie od zawartej w kodeksie postępowania administracyjnego regulacji. Decyzja, na mocy której starosta stwierdza nieważność uchwały walnego zgromadzenia jest decyzją ostateczną, podczas gdy decyzje wydane w I instancji przez organy wskazane w art. $127 \S 3$ k.p.a. nie posiadają tego przymiotu. Na mocy art. $16 \S 1$ zd. 1 k.p.a, decyzjami ostatecznymi są bowiem decyzje, od których nie służy odwołanie $\mathrm{w}$ administracyjnym toku instancji lub wniosek o ponowne rozpatrzenie sprawy. Regulacja zwarta w Prawie wodnym stanowi wyjątek od zasady dwuinstancyjności wyrażonej w art. 78 Konstytucji Rzeczypospolitej Polskiej ${ }^{18}$ z dnia 2 kwietnia 1997 r. $^{19}$ Pojmowanie rozwiązania przyjętego $\mathrm{w}$ prawie wodnym przez pryzmat regulacji postępowania administracyjnego może prowadzić do błędnych wniosków, iż kontrola sądowa możliwa jest dopiero po ponownym rozpoznaniu sprawy. Jak słusznie wskazano w literaturze przedmiotu, decyzja, na mocy której starosta stwierdza nieważność uchwały walnego zgromadzenia o rozwiązaniu spółki wodnej, nie podlega kontroli wewnętrznej starosty, gdyż jest decyzją ostateczną, stąd też podlega zaskarżeniu do sądu administracyjnego ${ }^{20}$. Powyższe stanowisko potwierdza postanowienie Wojewódzkiego Sądu Administracyjnego w Łodzi z dnia 7 października 2008 r., II SA/Łd446/08, Lex nr 504536, zgodnie z którym tryb wewnętrznej kontroli decyzji przez starostę nie ma zastosowania $w$ przypadku decyzji starosty stwierdzającej nieważność uchwaty spótki wodnej.

Artykuł 181 ustawy Prawo wodne przewiduje również możliwość rozwiązania spółki wodnej decyzją starosty. W prze-

16 Tekst jednolity Dz. U. 2000, Nr 98, poz. 1071 ze zm.; powoływana dalej jako k.p.a.

17 J. Rotko, op. cit., s. 434.

18 Dz. U. 1997, Nr 78, poz. 483 ze zm., powoływana dalej jako Konstytucja.

19 K. Glibowski, [w:] Kodeks postępowania administracyjnego. Komentar\% pod red. Marka Wierzbowskiego i Aleksandry Wiktorowskiej, Warszawa 2011, s. 95 i 709.

20 J. Szachułowicz, op. cit., s. 434-435. 
ciwieństwie do woli walnego zgromadzenia, wyrażającej się w postaci uchwały, starosta może zadecydować o rozwiązaniu spółki wodnej tylko w określonych przepisami ustawy okolicznościach, które enumeratywnie zostały wymienione w art. 181 ust. 2 prawa wodnego ${ }^{21}$. W przepisie tym zastosowano alternatywę rozłączną, stąd nie ma wymogu, aby wszystkie przesłanki nastąpiły jednocześnie.

Pierwszą przesłanką, która może stać się przyczyną rozwiązania spółki wodnej przez starostę $\mathrm{w}$ drodze decyzji, jest działalność spółki, która narusza prawo lub jej statut. We wskazanej regulacji nie chodzi o jakiekolwiek naruszenia prawa lub statutu, jednak o naruszenia uciążliwe i o dużej szkodliwości. Decyzja starosty o rozwiązaniu spółki wodnej, w obliczu wskazanych naruszeń, ma zakończyć byt prawny podmiotu, którego działalności zgodnej z prawem nie można przywrócić, stosując inne znane prawu środki ${ }^{22}$. Decyzja ta powinna nastąpić po przeprowadzeniu wnikliwego postępowania wyjaśniającego, mającego na celu dokonanie ustaleń faktycznych, w oparciu o konkretne dowody, przy czynnym udziale stron postępowania ${ }^{23}$.

Przykładem okoliczności wypełniającej dyspozycję art. 181 ust. 2 pkt 1 ustawy Prawo wodne jest chociażby sytuacja, w której zachodzą wskazane w statucie spółki okoliczności, uzasadniające rozwiązanie spółki wodnej, zaś nie dochodzi do zwołania walnego zgromadzenia wspólników, celem podjęcia stosownej uchwały. Taka sytuacja niewątpliwie narusza statut spółki i stanowi uzasadnienie dla podjęcia przez starostę decyzji o jej rozwiązaniu. Oczywiście w obliczu takich zdarzeń w statucie spółki wodnej mogą zostać dokonane następcze zmiany. Co istotne, uchwała o następczej zmianie statutu będzie również podlegała kontroli starosty, który może stwierdzić jej nieważność w trybie opisanym w niniejszym opracowaniu. Również nieprzekazywanie uchwał staroście, nieaktualizowanie statutu

${ }^{21}$ Ibidem, s. 437.

22 J. Rotko, op. cit. s. 436.

23 Uzasadnienie do wyroku Wojewódzkiego Sądu Administracyjnego 2/2012 w Bydgoszczy z dnia 3 marca 2009 r., II SA/Bd 905/08, Legalis. 
spółki, jak również niezłożenie wniosku o wpisanie spółki do katastru wodnego, może stanowić podstawę wskazanej decyzji.

Przyczynę rozwiązania spółki wodnej w trybie art. 181 ust. 2 pkt 1 ustawy Prawo wodne stanowić może również, o czym rozstrzygał Wojewódzki Sąd Administracyjny w Bydgoszczy wyrokiem z dnia 3 marca 2009 r., II SA/Bd 905/08, Legalis, niewykonywanie przez Zarząd wskazań Komisji Rewizyjnej i uchwał Walnego Zgromadzenia w sprawie modernizacji oczyszczalni ścieków, mimo wcześniejszego opracowania dokumentacji oraz zmian w statucie.

Kolejną okolicznością, która może skutkować zakończeniem bytu prawnego spółki wodnej na mocy decyzji starosty, jest upływ terminu, na jaki został ustanowiony zarząd komisaryczny a walne zgromadzenie nie dokonało wyboru nowego zarządu. Zarząd komisaryczny ustanawiany jest w przypadku, kiedy decyzją starosty odwołany zostanie zarząd dotychczas sprawujący swoją funkcję. Decyzję taką starosta może podjąć, jeśli zarząd, o którym mowa, dopuści się powtarzającego się naruszenia prawa lub statutu. Oczywiście samo odwołanie zarządu przez starostę nie oznacza powołania zarządu komisarycznego. Dzieje się tak jedynie w przypadku, kiedy najwyższy organ spółki - walne zgromadzenie - nie dokona wyboru nowego zarządu. Ustawodawca przewidział termin roczny kadencji zarządu komisarycznego. Jest to okres, w ciągu którego walne zgromadzenie powinno powołać nowy zarząd, zaś sankcją za niespełnienie obowiązku jest omawiana możliwość rozwiązania spółki przez organ nadzorczy. Niewywiązanie się z obowiązku powołania nowego zarządu świadczy o tym, iż członkowie spółki nie rozumieją jej zadań, które służą zarówno im jak i dobru społecznemu, co oznacza, że doszło do rozkładu fundamentów leżących u podstaw funkcjonowania spółki²4.

Ostatnią z wymienionych okoliczności uzasadniających rozwiązanie spółki wodnej w drodze decyzji starosty, jest sytuacja, kiedy liczba członków spółki będzie mniejsza niż 3 wspólników, czyli będzie niższa niż ustawowe minimum przewidziane w art. 165 ust. 1 Prawa wodnego. Wynika z tego, że zdaniem

24 J. Szachułowicz, op. cit., s. 436-437. 
ustawodawcy cele, do jakich została powołana spółka wodna, mogą być osiągnięte jedynie w składzie minimum 3 członków będących osobami fizycznymi lub osobami prawnymi ${ }^{25}$.

Wskazana wyżej możliwość rozwiązania spółki wodnej przez starostę $\mathrm{w}$ drodze decyzji, $\mathrm{w}$ obliczu zaistniałych przesłanek, stanowi jego prawo, nie zaś obowiązek i to od uznania starosty będzie zależało ostateczne rozważenie, czy waga zaistniałych okoliczności uzasadnia podjęcie tak radykalnej w skutkach decyzji.

Zgodnie z tezą wyroku Wojewódzkiego Sądu Administracyjnego w Bydgoszczy z dnia 3 marca 2009 r., II SA/Bd 905/08, (Legalis) użycie przez ustawodawce $w$ przepisie art. 181 ust. 2 pkt 1 ustawy Prawo wodne (Dz.U. z 2005 r. Nr 239, poz. 2019 z późn. zm.) zwrotu „może” przesądza, że podejmowane na jego podstawie rozstrzygnięcia maja charakter uznaniowy, to jest organy administracji mogq nałożyć np. określone obowiazki, ale nie musza, gdyż celowość podjęcia takich działań została uzależniona od dokonanej przez nie oceny". W uzasadnieniu do wskazanego wyroku Wojewódzki Sąd Administracyjny słusznie wskazał, iż decyzja starosty o rozwiązaniu spółki wodnej ma charakter uznaniowy, stąd też celowość wydania przez starostę decyzji o rozwiązaniu spółki wodnej uzależniona jest od przeprowadzonej przez ten organ nadzorczy oceny. Zgodnie z poglądem wyrażonym $\mathrm{w}$ literaturze przedmiotu, konsekwencją użycia przez ustawodawce słowa "może" jest "nakaz rozważenia potrzeby zastosowania sankcji ${ }^{26}$. Należy jednak wskazać, iż ocena ta i działania podejmowane przez starostę nie mogą mieć charakteru dowolnego, tylko muszą być one zgodne z prawem. W takiej sytuacji bada się, czy organ miał prawo działania w ramach uznania administracyjnego i czy nie zostały przekroczone jego granice $^{27}$. Z powyższego wynika, iż organ administracji publicznej,

25 Ibidem, s. 438.

26 M. Wincenciak, Sankcje $w$ prawie administracyjnym i procedura ich wymierzania, Warszawa 2008, s. 121.

27 M. Jaśkowska, M. Mincer, Uznanie administracyjne, Toruń 1983, s. 55 i nast. 
a w tym przypadku starosta, może dokonać wyboru pomiędzy dopuszczonymi przez ustawę, równoważnymi rozwiązaniami ${ }^{28}$.

Decyzja starosty, która ma charakter uznania administracyjnego, podlega kontroli sądu administracyjnego pod względem prawidłowości postępowania poprzedzającego wydanie decyzji i jego zgodności z art. 7 k.p.a., art. 10 § 1 k.p.a., art. 77 $\S 1$ k.p.a., art. 80 k.p.a. oraz art. $107 \S 1$ i 3 k.p.a. W takiej sytuacji sąd administracyjny bada, czy wszystkie istotne okoliczności sprawy zostały wyjaśnione, czy stan faktyczny został ustalony w sposób prawidłowy, oceniony zgodnie z przepisami prawa materialnego oraz czy pozostaje w zgodności z wynikami postępowania dowodowego. Sąd również bada, czy stronie zapewniono należyty udział w postępowaniu, umożliwiając jej wypowiedzenie się co do zebranych w sprawie dowodów i materiałów. Mając na względzie powyższe, starosta, wydając decyzję o rozwiązaniu spółki wodnej, powinièn ją uzasadnić w sposób należyty, w oparciu o zasady doświadczenia życiowego oraz logiki, z uwagi na to, że uznanie administracyjne nie jest tożsame z dowolnością.

Na zakończenie rozważań dotyczących uznania administracyjnego warto przytoczyć jedną z tez wyroku Naczelnego Sądu Administracyjnego z dnia 11 czerwca 1981 r., SA 820/81, (Centralna baza Orzeczeń Sądów Administracyjnych): organ administracji, działający na podstawie przepisów prawa materialnego przewidujących uznaniowy charakter rozstrzygnięcia, jest obowiazany - zgodnie z zasada z art. $7 \mathrm{Kpa}$ - załatwić sprawę $w$ sposób zgodny ze słusznym interesem obywatela, jeśli nie stoi temu na przeszkodzie interes społeczny, ani nie przekracza to możliwości organu administracji wynikających z przyznanych mu uprawnień $i$ środków.

Podjęcie uchwały o rozwiązaniu spółki wodnej przez walne zgromadzenie lub też wydanie decyzji w tym przedmiocie przez starostę, rozpoczyna czynności prowadzące do likwidacji. Rozwiązanie spółki wodnej następuje po przeprowadzeniu postępowania likwidacyjnego, natomiast postępowanie likwida-

${ }^{28}$ J. Zimmermann, Polska jurysdykcja administracyjna, Warszawa 1996, s. 116. 
cyjne rozpoczyna się od chwili otwarcia likwidacji. Spółka wodna, w okresie trwania postępowania likwidacyjnego, działa pod dotychczasową nazwą, jednak z dodaniem wyrazów $w$ likwidacji. Spółka zachowuje również osobowość prawną ${ }^{29}$.

Postawienie spółki w stan likwidacji wiąże się również z koniecznością powołania likwidatora. W przypadku podjęcia uchwały o rozwiązaniu spółki wodnej przez walne zgromadzenie, organ ten jest wyłącznie kompetentny do powołania likwidatora, którym może być członek zarządu lub inna osoba. Jednak w sytuacji, w której decyzję o rozwiązaniu spółki wodnej podejmuje starosta, ma on wyłączne prawo do powołania osoby likwidatora.

Ustawa Prawo wodne nie określa, w jakiej formie powinno nastąpić wyznaczenie likwidatora, jednak w literaturze przedmiotu pojawił się pogląd, iż do powołania likwidatora wystarczy umowa cywilno-prawna, zawarta pomiędzy likwidatorem a spółką wodną ${ }^{30}$. Z uwagi na to, iż zarząd jest organem wykonawczym spółki, do jego kompetencji należy składanie oświadczeń woli w imieniu spółki wodnej. Zasady reprezentacji spółki na zewnątrz mogą, zgodnie z art. 176 ust. 5 ustawy Prawo wodne, wynikać z postanowień statutu a jeżeli statut nie reguluje kwestii reprezentacji, zastosowanie mają przepisy Prawa wodnego. W takim przypadku oświadczenia woli w imieniu spółki wodnej może składać jeden członek zarządu - wówczas, gdy w skład zarządu wchodzą nie więcej niż dwie osoby. W pozostałych przypadkach wymagane jest współdziałanie dwóch członków zarządu.

Z uwagi na to, że likwidator wstępuje w prawa i obowiązki zarządu spółki wodnej, jest on uprawniony do kontynuowania jego czynności, również do reprezentowania spółki na zewnątrz i do składania oświadczeń w jej imieniu. Jedyny wyjątek polega na tym, że podejmowane przez likwidatora działania ukierunkowane są na zakończenie, nie zaś na rozwijanie działalności spółki wodnej ${ }^{31}$.

29 J. Szachułowicz, op. cit., s. 438.

30 J. Rotko, op. cit., s. 437.

31 J. Szachułowicz, op. cit., s. 439. 
Przepisy ustawy Prawo wodne dotyczące postępowania likwidacyjnego spółki są bardzo lakoniczne i nie precyzują, jakie czynności mają być podjęte przez likwidatora $\mathrm{w}$ ramach tego postępowania. Przepis $\S 35$ powoływanego rozporządzenia w sprawie spółek wodnych i ich związków wymieniał, jakie obowiązki w szczególności mają być podjęte przez likwidatora. Jak się wydaje, czynności podejmowane przez likwidatora spółki wodnej w obowiązującym stanie prawnym są zbieżne z czynnościami podejmowanymi przez likwidatora pod rządami Prawa wodnego z 24 października 1979 r. Czyniąc takie założenie, można stwierdzić, iż $\mathrm{w}$ ramach postepowania likwidacyjnego likwidator jest obowiązany do sporządzenia bilansu na dzień rozpoczęcia i zakończenia likwidacji, zakończenia bieżących interesów spółki, ściągnięcia wierzytelnoŝci, wypełnienie zobowiązań i upłynnienie majątku spółki. W przypadku powołania większej liczby likwidatorów, odpowiednio stosowany będzie art. 176 ust. 5 ustawy Prawo wodne, regulujący kwestię składania oświadczeń w imieniu spółki. Co istotne, walne zgromadzenie oraz komisja rewizyjna działają pomimo otwarcia postępowania likwidacyjnego a ponadto uprawnienia, które im przysługiwały w stosunku do zarządu, przechodzą na ustanowionego likwidatora. Koszty wynagradzania likwidatora ponosi spółka i to bez względu na to, czy został on powołany uchwałą walnego zgromadzenia, czy też wyznaczony przez starostę. O wysokości wynagrodzenia należnego likwidatorowi decyduje starosta $\mathrm{w}$ formie decyzji ${ }^{32}$.

Likwidator zobowiązany jest do wypełniania zobowiązań spółki wodnej w określonej kolejności. Warto zauważyć, iż kolejność przewidziana w Prawie wodnym nie pokrywa się z kolejnością przewidzianą $\mathrm{w}$ prawie upadłościowym, zaś zbliżona jest do regulacji art. 125 ustawy z dnia 16 września 1982 r. Prawo spółdzielcze ${ }^{33}$, choć w tych przepisach wynagrodzenie likwidatora znajduje się na pierwszym miejscu, podczas gdy w prawie wodnym przewidziano, że koszty prowadzenia likwidacji mają być zaspokojone dopiero po zobowiązaniach ze stosunku pracy

32 Ibidem, s. 439.

33 Tekst jednolity Dz. U. 2003, Nr 188, poz. 1848 ze zm. 
oraz zobowiązaniach w zakresie danin publicznych. W ostatniej kolejności zaspokaja się pozostałe zobowiązania ${ }^{34}$.

W pierwszej kolejności mają być zaspokajane zobowiązania ze stosunku pracy, która w prawie polskim korzysta ze szczególnej ochrony, zgodnie z art. 24 Konstytucji. Za poglądami doktryny prawa upadłościowego i naprawczego można przyjąć, iż do zobowiązań ze stosunku pracy zalicza się należności za pracę tylko ze stosunku pracy nie zaś zlecenia, umowy o dzieło ani innych umów pokrewnych, na podstawie których świadczona jest praca. Wskazane zobowiązania należałoby zaliczyć do wymienionych w art. 183 pkt 4 ustawy innych zobowiązań. Do zobowiązań ze stosunku pracy należy również zaliczyć, poza płacą zasadniczą z dodatkami, inne roszczenia związane ze stosunkiem pracy, jak choćby roszczenie odszkodowawcze z tytułu bezprawnego rozwiązania umowy o pracę, premie oraz odprawy z tytułu grupowych zwolnień z pracy ${ }^{35}$.

Następnie pokrywane mają być zobowiązania w zakresie danin publicznych. Obowiązek ponoszenia ciężarów i świadczeń publicznych, w tym podatków, określonych w ustawie uregulowany został w art. 84 Konstytucji, zaś określenie, co znajduje się pod pojęciem danina publiczna, uregulowano w ustawie z dnia 27 sierpnia 2009 r. o finansach publicznych ${ }^{36}$. Jak najszybsze wykonanie tego zobowiązania jest podyktowane sankcjami grożącymi za zwłokę. Szybkie zaspokojenie świadczeń podatkowych pozwala uniknąć naliczania odsetek od zaległości podatkowych ${ }^{37}$.

Ustawa Prawo wodne nie zawiera regulacji dotyczącej nadwyżki bądź niedoboru finansowego. W przypadku nadwyżki, można ją rozdzielić na członków spółki wodnej, w stosunku do płaconych przez nich składek i wartości świadczonych usług. Z kolei problem niedoboru może być rozwiązany poprzez podjęcie przez walne zgromadzenie wspólników spółki wodnej

34 J. Rotko, op. cit., s. 437.

35 S. Gurgul, Prawo upadłościowe i naprawcze. Komentarz, Warszawa 2011, s.

37 J. Szachułowicz, op. cit., s. 440. 
uchwały o obowiązku poniesienia przez członków świadczeń na rzecz spółki. Ułatwieniu ściągania świadczeń na rzecz spółki służy regulacja art. 170 ust. 5 Prawa wodnego, zgodnie z którą do egzekucji świadczeń na rzecz spółki wodnej stosuje się odpowiednio przepisy o egzekucji należności podatkowych. W przypadku bezskuteczności egzekucji niezaspokojone zobowiązania zostaną umorzone ${ }^{38}$.

Zgodnie z regulacją art. 182 ust. 6 Prawa wodnego likwidator odpowiada za szkody powstałe wskutek prowadzenia postępowania likwidacyjnego z naruszeniem zasad określonych w ustawie lub w statucie spółki wodnej. Naruszeniem przepisów ustawy będzie również naruszenie ustawowej kolejności zaspokajania zobowiązań przypadających od spółki wodnej będącej w likwidacji. Przepis ten wprowadza zawężoną bezprawność czynu likwidatora, która ogranicza się jedynie do naruszenia przepisów ustawy i postanowień statutu. Odpowiedzialność likwidatora rodzi się przez sam fakt wyrządzenia szkody, jednak może on uwolnić się od odpowiedzialności wykazując, iż nie ponosi winy albo, że brak jest związku przyczynowo-skutkowego pomiędzy jego działaniem lub zaniechaniem a szkodą. Jeżeli do przeprowadzenia postępowania likwidacyjnego powołano więcej niż jednego likwidatora, we wspomnianej regulacji art. 182 ust. 6 prawa wodnego przewidziano odpowiedzialność solidarną likwidatorów. Do dochodzenia odpowiedzialności za szkody wyrządzone przez likwidatora służy droga sądowa ${ }^{39}$.

Po zakończeniu postępowania likwidacyjnego likwidator przedstawia do zatwierdzenia walnemu zgromadzeniu ostateczne rachunki i sprawozdania. Zgodnie z art. 184 ustawy starosta, po otrzymaniu uchwały walnego zgromadzenia spółki wodnej w likwidacji o zatwierdzeniu ostatecznych rachunków i sprawozdań likwidatora, występuje z wnioskiem o wykreślenie spółki wodnej z katastru wodnego. Wyżej wskazaną uchwałę przedkłada staroście likwidator, zaś starosta, w stosunku do

38 Ibidem.

J. Szachułowicz, op. cit., s. 439. 
uchwały walnego zgromadzenia, ma uprawnienia nadzorcze wynikające $\mathrm{z}$ art. 179 prawa wodnego ${ }^{40}$.

W doktrynie pojawił się problem dotyczący momentu utraty przez spółkę wodną osobowości prawnej. Nie ulega wątpliwości, iż osobowość prawną spółka zyskuje z chwilą uprawomocnienia się decyzji starosty o zatwierdzeniu statutu spółki wodnej, zaś wpis do katastru wodnego ma jedynie charakter porządkowy - deklaratoryjny ${ }^{41}$. Sytuacja nie jest jednak tak jasna w przypadku utraty przez spółkę osobowości prawnej. W przedmiocie tego zagadnienia zostały wypracowane przez doktrynę dwa poglądy.

Według pierwszego z nich utrata przez spółkę osobowości prawnej następuję w momencie wykreślenia spółki z katastru wodnego. Przy uzasadnieniu tego poglądu wskazuje się, że skoro nabycie osobowości prawnej przez spółkę następuje nie przez samo podjęcie uchwały o jej utworzeniu a po uprawomocnieniu się decyzji starosty zatwierdzającej uchwałę walnego zgromadzenia, to utrata przez spółkę osobowości prawnej powinna odbywać się w podobny sposób - po otrzymaniu uchwały walnego zgromadzenia o zatwierdzeniu sprawozdań i rachunków postępowania likwidacyjnego starosta powinien wydać zatwierdzającą decyzję, której uprawomocnienie prowadziłoby do utraty przez spółkę osobowości prawnej. Jednak art. 184 prawa wodnego nie przewiduje takiego rozwiązania. Zgodnie z jego treścią starosta po otrzymaniu uchwały walnego zgromadzenia spótki wodnej $w$ likwidacji o zatwierdzeniu ostatecznych rachunków i sprawozdan likwidatora występuje z wnioskiem o wykreślenie spótki wodnej z katastru wodnego. Według omawianej koncepcji, ze względów porządkowych oraz dla bezpieczeństwa prawnego, utrata osobowości prawnej przez spółkę wodną w likwidacji następuje $\mathrm{w}$ momencie wykreślenia jej z katastru wodnego mimo, iż sam wpis do katastru nie ma charakteru konstytutywnego a deklaratoryjny ${ }^{42}$.

40 J. Rotko, op. cit., s. 437.

41 J. Szachułowicz, op. cit., s. 441.

42 J. Rotko, op. cit., s. 438. 
Według drugiego poglądu likwidacja spółki wodnej w sensie materialno-prawnym następuje z chwilą zatwierdzenia przez walne zgromadzenie ostatecznych rachunków i sprawozdań likwidatora z przeprowadzonego postępowania likwidacyjnego. $\mathrm{Z}$ uwagi na to, że wpis do rejestru ma charakter deklaratoryjny, jest on jedynie formalnym potwierdzeniem rozwiązania spółki, która jako podmiot prawa formalnie istnieje do momentu jej wykreślenia z katastru wodnego. Z powyższego wynika, że spółka wodna traci osobowość prawną w momencie podjęcia uchwały zatwierdzającej sprawozdania i rachunki likwidatora z przeprowadzonego postępowania likwidacyjnego ${ }^{43}$.

Do tego problemu odniósł się również Wojewódzki Sąd Administracyjny w Gorzowie Wielkopolskim w wyroku z dnia 29 grudnia 2009 r., II SA/Go 888/09, Lex nr 582970, który w uzasadnieniu prawnym do wyroku wypowiedział się również na temat utraty przez spółkę wodną osobowości prawnej. Jest on zdania, że najwcześniejszym momentem, od którego można rozważać ustanie bytu spółki wodnej, jest zatwierdzenie ostatecznych rachunków i sprawozdan likwidatora. Z uwagi na to, że zgodnie z art. 153 ust. 1 Prawa wodnego kataster wodny jest jedynie systemem informacyjnym o gospodarowaniu wodami, nie jest on objęty domniemaniem zgodności z rzeczywistym stanem prawnym a dane $\mathrm{w}$ nim ujęte nie noszą cech konstytutywności. Z tego wynika, iż wykreślenie, podobnie jak wpis, ma jedynie charakter porządkowy - deklaratoryjny, zaś charakter kształtujący ma podjęcie przez walne zgromadzenie członków spółki wodnej uchwały o zatwierdzeniu ostatecznych rachunków i sprawozdań likwidatora. Sąd wskazał, że możliwość kontroli uchwały walnego zgromadzenia zatwierdzającej ostateczne rachunki i sprawozdania likwidatora przez stwierdzenie jej nieważności, które wywołuje skutek ex tunc, nie zmienia charakteru tej uchwały. Jego zdaniem z art. 179 ust. 2 Prawa wodnego należy wnosić, $i \dot{z}$ skutek uchwały o zatwierdzeniu ostatecznych rachunków i sprawozdań likwidatora polegający na ustaniu bytu prawnego (osobowości prawnej) spótki następuje z dniem

43 J. Szachułowicz, op. cit., s. 441, K. I. Kobus-Ogrodniczak, op. cit., s. 132. 
jej podjęcia. Jeśli zaś przed uptywem 30 dnia od daty doręczenia uchwaty organu spótki wodnej organowi nadzoru, organ ten wyda decyzję, o której mowa $w$ art. 179 ust. 2 Prawa wodnego, skutek ex tunc spowoduje powrotne nadanie spótce wodnej „bytu prawnego" a jej reprezentantowi (likwidatora) uprawnien do działania, w tym wynikajacych z ust. 4 art. 179 tego Prawa.

Z wyżej przedstawionego stanowiska Wojewódzkiego Sądu Administracyjnego w Gorzowie Wielkopolskim wynika, iż przychylił się on do drugiej prezentowanej wyżej koncepcji, zgodnie z którą utrata osobowości prawnej przez spółkę wodną następuje $\mathrm{z}$ chwila podjęcia uchwały o zatwierdzeniu ostatecznych rachunków i sprawozdań likwidatora. Wydaje się, że na mocy obowiązujących przepisów prawa wodnego, jest to koncepcja bardziej poprawna, jednak nie oczywista.

Podsumowując przedstawione wyżej rozważania, należy zauważyć, iż regulacja dotycząca zakończenia bytu prawnego spółki wodnej znacznie odbiega od regulacji zawartych w ustawie prawo upadłościowe i naprawcze oraz kodeksie spółek handlowych, traktując kwestię zakończenia bytu prawnego spółki wodnej bardzo lakonicznie. Oczywistym jest, że spółki wodnej nie należy porównywać ze spółkami kapitałowymi, jednak, zdaniem autora, regulacja związana z likwidacją spółki wodnej powinna być zbliżona do regulacji związanej z likwidacją spółki z ograniczoną odpowiedzialnością.

W niniejszym opracowaniu starano się przedstawić podstawowe problemy, zarówno teoretyczne jak i praktyczne, związane z rozwiązaniem spółki wodnej. Mając na względzie powyższe rozważania, przede wszystkim stawia się postulat de lege ferenda włączenia do ustawy prawo wodne przepisu wyraźnie określającego moment utraty przez spółkę osobowości prawnej, podobnie jak ma to miejsce przy art. 165 ust. 4 ustawy Prawo wodne, określającym moment uzyskania przez spółkę wodną osobowości prawnej. Jak się okazuje, jest to problem, który budzi wątpliwości nie tylko w doktrynie, ale stał się również przedmiotem rozważań na tle konkretnie rozstrzyganej przez sąd administracyjny sprawy. 


\section{BIBLIOGRAFIA}

Ciepaj M., Spótki wodne w systemie gospodarki wodnej, Opole 1989.

Glibowski K., [w:] M. Wierzbowski (red.), A. Wiktorowska (red.), Kodeks postępowania administracyjnego. Komentarz, Warszawa 2011.

Gurgul S., Prawo upadtościowe i naprawcze. Komentarz, Warszawa 2011.

Jaśkowska M., Mincer M., Uznanie administracyjne, Torun 1983.

Koza I., Osuch-Chacińska L., Pełda-Sypuła M., Rytlewski M., Noweprawo wodne, Zielona Góra 2002.

Kobus-Ogrodniczak K. I., Korzystanie z wód - problemy prawne, Toruń 2011.

Paczuski R., Spótki wodne - cele, zadania, prawne podstawy organizacji oraz perspektywy ich rozwoju w kontekście zachodzaccych zmian, Toruń 2006.

Paczuski R., Spótki wodne. Historia. Podstawy prawne działania. Nowe tendencje, Warszawa 1989.

Rotko J., [w:] J. Rotko (red.) Prawo wodne. Komentarz, Wrocław 2002.

Smoktunowicz E, (red.), Wielka Encyklopedia Prawa, Białystok 2000.

Szachułowicz J., Prawo wodne. Komentarz, Warszawa 2010.

Wincenciak M., Sankcje $w$ prawie administracyjnym i procedura ich wymierzania, Warszawa 2008.

Zimmermann J., Polska jurysdykcja administracyjna, Warszawa 1996.

Kontakt e-mail:

kasiakierzkowska@gmail.com 